This PDF is a selection from a published volume from the National Bureau of Economic Research

Volume Title: U.S. Engineering in a Global Economy

Volume Author/Editor: Richard B. Freeman and Hal Salzman, editors

Volume Publisher: University of Chicago Press

Volume ISBNs: 978-0-226-46833-4 (cloth); 978-0-226-46847-1 (e-ISBN)

Volume URL: http://www.nber.org/books/free12-1

Conference Date: September 26-27, 2011

Publication Date: April 2018

Chapter Title: Bridging the Gaps between Engineering Education and Practice

Chapter Author(s): Samantha R. Brunhaver, Russell F. Korte, Stephen R. Barley, Sheri D. Sheppard

Chapter URL: http://www.nber.org/chapters/c12687

Chapter pages in book: (p. $129-163)$ 


\title{
Bridging the Gaps between Engineering Education and Practice
}

\author{
Samantha R. Brunhaver, Russell F. Korte, \\ Stephen R. Barley, and Sheri D. Sheppard
}

Increasingly, American engineers contend with challenges at work including rapid technological innovation and the needs of changing workplaces (Duderstadt 2008; National Academy of Engineering 2008b; National Research Council 2007). In response, industry, government, and professional societies have called on educators to better prepare engineering students by emphasizing not only technical but professional competencies (Jamieson and Lohmann 2009; Sheppard et al. 2008; Shuman, Besterfield-Sacre, and McGourty 2005). There is a consensus in the engineering community that those competencies include communication skills, business skills, teamwork skills, creativity, lifelong-learning skills, and problem-solving skills (ABET 2011; American Society of Civil Engineers 2008; McMasters and Matsch 1996; National Academy of Engineering 2004).

Yet, despite calls for reform, engineering programs are often based on an outdated image of engineering practice that is misaligned with reality (Duderstadt 2008; National Research Council 2007; Sheppard et al. 2008;

Samantha R. Brunhaver is assistant professor of engineering at The Polytechnic School at Arizona State University. Russell F. Korte is associate professor in Organizational Learning, Performance, and Change at Colorado State University. Stephen R. Barley is the Christian A. Felipe Professor of Technology Management at the College of Engineering at the University of California, Santa Barbara. Sheri D. Sheppard is the Burton J. and Deedee McMurtry University Fellow in Undergraduate Education and professor of mechanical engineering at Stanford University.

This research was supported by two National Science Foundation (NSF) grants no. 0227558 and no. 1022644, as well as a Stanford Graduate Fellowship from Stanford University. The authors thank Michelle Grau and Michelle Warner for their assistance with coding, the editors for helpful comments on earlier versions of this chapter, and the engineers who participated in our research. For acknowledgments, sources of research support, and disclosure of the authors' material financial relationships, if any, please see http://www.nber.org/chapters /c12687.ack. 
Vest 2008). Although society has long looked to higher education to develop the nation's workforce (Sullivan and Rosin 2008), employers, faculty, and even students have questioned whether engineering programs meet this goal. For example, in 2004 almost a quarter of employers reported that engineering graduates were less skilled in problem solving and less aware of organizational contexts and constraints than graduates ten years earlier. A third of the teaching faculty reported that the students were less able in math and science and had worse technical skills than their forerunners (Lattuca, Terenzini, and Volkwein 2006). Other research has shown that many engineering students remain uncertain about what engineering is and what engineers do, even by the time they graduate (Matusovich et al. 2009).

Our interviews together with other studies identify shortcomings that engineering programs have in preparing students for practice. First, as more and more U.S. corporations downsize and outsource, graduates looking for engineering work face pressure to stay relevant and adapt to new industry needs (Shuman, Besterfield-Sacre, and McGourty 2005). Second, graduates may need additional training to acquire missing competencies, which comes at a cost to their employers (Salzman 2007). Third, uncertainty about what engineering really involves and feelings of being ill prepared may convince some graduates to abandon engineering. Two years after graduation 28 percent of all engineering graduates from the classes of 2008 and 2009 were working in fields outside of engineering, including mathematics and computer science (National Science Foundation 2010). Similarly, 20 percent of engineering seniors in 2007 reported that they were unsure about pursuing an engineering career (Atman et al. 2010). Their uncertainty partially reflects a nationwide loss of interest in engineering, a belief that engineering careers are no longer secure, and the realization that other professions pay higher wages (Chubin, May, and Babco 2005; Duderstadt 2008; Lowell and Salzman 2007; Shuman, Besterfield-Sacre, and McGourty 2005). Students' limited understanding of what engineering entails and the skills it requires may also lead them to reject engineering careers (Lichtenstein et al. 2009; National Academy of Engineering 2008a).

The studies described above support Trevelyan's (2007) claim that a better understanding of engineering practice is needed to inform students' career choices and improve their preparedness to work in this field. One of the best ways to accomplish this is to study engineering students and young engineers who have just entered the workforce and the challenges they encounter and how they make sense of these challenges. This chapter uses interviews with engineering students and newly hired engineers from the Academic Pathways Study (Sheppard et al. 2009) and the Engineering Pathways Study (Sheppard et al. 2011) to examine disjunctures between engineering education and professional practice and describes possible ways to better connect training to practice. 


\subsection{Background}

Although most studies of how to prepare engineering students more effectively for professional practice focus on mastering competencies that educators and employers think are important (e.g., Bankel et al. 2003; Lattuca, Terenzini, and Volkwein 2006; Meier, Williams, and Humphreys 2000), some studies approach the problem by exploring how young engineers perceive the relevance of their education. Most of the latter have studied young engineers in the workplace, while a few have studied engineering students currently in school. Dunsmore, Turns, and Yellin (2011) found that mechanical engineering students sharply contrasted their academic experience with professional practice. Students thought of work, but not school, as the "real world." They identified teamwork and communication as real-world skills crucial for success, but still believed that such skills were less important than skills like the ability to design. Seniors surveyed in the Academic Pathways Study also said communication and teamwork were important skills (Atman et al. 2010), but thought their school experiences were unrelated to engineering work (Sheppard et al. 2010). Even the 50 percent who reported exposure to engineering through internships, jobs, company visits, and research experiences had no greater appreciation for the relevance of professional and interpersonal skills than did freshmen (Sheppard et al. 2010; Atman et al. 2010). These results suggest that while senior engineering students think that communication and teamwork are important, they may not understand how these skills are actually used in practice.

Many more studies have asked practicing engineers how well their undergraduate education prepared them for their current work. Across these studies, working engineers report that knowing how to communicate and work with other people is paramount and that most of what they now do was learned on the job. Roughly half of MIT's mechanical engineering alumni from the classes of 1992-1996 reported using professional skills, ${ }^{1}$ interpersonal skills, and independent-thinking skills almost daily in their work and said that they had learned these skills on the job (Seering 2009). In contrast, the MIT alumni reported hardly ever using the theoretical knowledge they learned in college (for example, thermodynamics and fluid mechanics). Almost identical results were found in a study of practicing engineers as part of the National Science Foundation (NSF)-funded Aligning Educa-

1. Seering (2009) operationalized professional skills as professional ethics and integrity, responsibility and accountability, professional behavior, proactively planning for one's career, and continuous learning; personal skills as initiative and willingness to take risks, perseverance and flexibility, creative thinking, and time and resource management; and independent thinking skills as skills in working independently, skills in setting project goals, ability to extract and evaluate relevant knowledge; and confidence in one's own skills and abilities. 
tional Experiences with Ways of Knowing Engineering (AWAKEN) project. The respondents in this study considered communication, problem solving, ethics, lifelong learning, and business skills to be essential to their work (Anderson et al. 2009). Two-thirds said that their schooling prepared them well for engineering practice and half said they still used skills they learned as undergraduates. But for many, "real" engineering consisted only of technical problem solving (Grohowski-Nicometo, Nathans-Kelly, and Anderson 2009), and most said that beyond the ability to think analytically, what they need to know at work they learned after graduating (Anderson et al. 2011). Passow (2012) found that engineers who graduated from a large, midwestern university in the 1990s and first decade of the twenty-first century also rated teamwork, communication, problem solving, and analytical skills as important in their professional experience. As a part of the Prototyping the Engineer of 2020 (P2P) study, Lattuca and colleagues (Lattuca et al. 2014) discovered that engineering alumni from thirty-one institutions rated communication skills, teamwork skills, and professional skills as highly important to their current work. Of these three, teamwork was perceived as having been the most heavily emphasized in their undergraduate curricula. ${ }^{2}$

Finally, as part of the NSF-funded Academic Pathways Study, Korte, Sheppard, and Jordan (2008) interviewed young engineers at a global automobile manufacturer to identify differences between their experiences at work and school and found that the company's social and organizational context set the problems and processes on which the engineers worked. These problems were often more complex, ambiguous, and political than those the engineers had encountered in school. Additionally, how the engineers perceived and learned about engineering work depended to a large extent on their interactions with coworkers in their work groups (Korte 2009, 2010).

The foregoing studies illuminate the relation between engineering education and practice, but have limitations that this chapter seeks to fill. More than half of the studies rely solely on survey data (Anderson et al. 2009; Atman et al. 2010; Lattuca et al. 2014; Passow 2012; Seering 2009; Sheppard et al. 2010; Trevelyan and Tilli 2008; Trevelyan 2008) that allow participants to voice their perspectives within the scope of defined response options, but

2. American engineers are not unique in their perceptions of their education's relevance. In a longitudinal study of early career professionals in the United Kingdom, most engineers differentiated between learning in school, which emphasized theory, and learning in the workplace, which emphasized communication, teamwork, leadership, decision making, reflection, and awareness (Eraut 2009). In another longitudinal study, Trevelyan and Tilli (2008) found engineers who graduated from the University of Western Australia (UWA) in 2006 spent, on average, 60 percent of their time interacting with other people at work. Ten percent said they wished they had been taught interpersonal skills at UWA, and interpersonal skills was the area in which engineers were most likely to report needing further training. Like American engineers, the Australians reported learning most of what they needed know on their own or from their coworkers (Trevelyan 2008). 
that give no opportunity for researchers to acquire a deeper contextually sensitive understanding of young engineers' experiences at work. Most of the studies sample engineers from or working in a handful of schools or organizations. ${ }^{3}$ Most important, each study captured only one side of the school-to-work transition, asking engineering students to anticipate future engineering practice, or asking engineering practitioners to reflect back on their academic preparation. ${ }^{4}$ To add to the existing knowledge, this chapter uses information obtained by structured and semistructured interviews that elicit participants' own perspectives on the relationship between their engineering education and practice. It uses two samples from the Academic Pathways Study (APS): ${ }^{5}$ a Workplace Sample of newly hired engineers and a Longitudinal Sample of junior-year engineering students in the APS who were later interviewed as early career professionals in the follow-on Engineering Pathways Study (EPS) (see Sheppard et al. 2011).

The Workplace Sample comprises fifty-seven newly hired engineers in their first full-time position since graduating, with whom we conducted semistructured forty-five- to ninety-minute interviews in the winter of 2007. As recent graduates, these individuals could best offer opinions about the differences between their engineering education and new employment. The participants worked in four U.S. organizations: a global automobile manufacturer (Car Company), a large food company (Food Manufacturer), a smaller computer components manufacturer (Computer Parts Company), and a state transportation agency (Transportation Department). The engineers at Car Company were mostly mechanical engineers, those at Food Manufacturer were chemical engineers, those at the Computer Parts Company were mechanical and chemical engineers, and those at Transportation Department were civil engineers. Car Company and Computer Parts Company assigned young engineers to permanent positions that involved both technical and project management work. Young engineers at Food Manufacturer and Transportation Department initially rotated through at least three departments before being assigned to a project management position.

To identify what young, practicing engineers need to know and whether they had learned that knowledge in school or on the job, we asked participants to reflect on one or two problems or projects to which they had been assigned and asked: "What knowledge and skills did you apply to work on the problem?" and "Where and how did you learn the knowledge and skills?" We also asked participants to reflect on their socialization experiences since

3. The exceptions are the Academic Pathways Study, the P2P study, and the AWAKEN study.

4. Even the two longitudinal studies (Eraut 2009; Trevelyan and Tilli 2008) focused exclusively on recently graduated engineers.

5. Funded by NSF, the APS was conducted between 2003 and 2007 under the auspices of the Center for the Advancement of Engineering Education (CAEE). Atman et al. (2010) provides details of the study's design and an overview of its findings. 
joining their organization and asked: "How did you learn the way things work at this company?" and "How did you learn what others expect of you on the job?" Finally, we asked participants about differences between their expectations as engineering students in school and experiences on the job.

Throughout the interviews, participants talked readily about knowledge and skills they used in their assignments and their work in general, differences between school and work, how much they used their overall education, and how well their education prepared them for their jobs. Passages in the interviews that deal with these topics, as well as the participants' answers to the questions above, provided data for the present analysis.

Table 4.1 summarizes demographic information on the Workplace Sample. All participants had been in their jobs for two months to three years, with an average duration of eleven months. Forty-five had internships in college and eighteen had interned with their current employer. Nine participants had master's degrees, and the rest had bachelor's degrees. Sixteen of the fifty-seven worked at Car Company, eighteen at Food Manufacturer, sixteen at Computer Parts Company, and seven at Transportation Department. Codes describing the knowledge and skills respondents used in completing specific assignments, learning about their organization, and their work in general emerged inductively from the data analysis and stayed close to the participants' own language (Patton 2002).

The Longitudinal Sample comprises two sets of interviews from three institutions in the western United States: a Technical Public institution (TPub), a Suburban Private university (SPri), and a Large Public university (LPub). The first set of interviews was conducted under the Academic Pathways Study (APS) in 2006, when the participants were junior-year engineering students (Sheppard et al. 2009). The second set of interviews were part of the Engineering Pathways Study (EPS) in 2011, four years after the participants earned their engineering bachelor's degrees (Sheppard et al. 2011). The two interviews allow us to compare how the same individuals thought about engineering as students with how they understood engineer-

\begin{tabular}{lccccc}
\hline & & \multicolumn{4}{c}{$\begin{array}{c}\text { Number who reported } \\
\text { internship }\end{array}$} \\
\cline { 5 - 6 } & Count & $\begin{array}{c}\text { Average time } \\
\text { since hire } \\
\text { (months) }\end{array}$ & $\begin{array}{c}\text { At any } \\
\text { company }\end{array}$ & $\begin{array}{c}\text { At current } \\
\text { company }\end{array}$ & $\begin{array}{c}\text { Number who } \\
\text { reported earning } \\
\text { master's degree }\end{array}$ \\
\hline All participants & $\mathbf{5 7}$ & $\mathbf{1 1 . 3}$ & $\mathbf{4 5}$ & $\mathbf{1 8}$ & $\mathbf{9}$ \\
Food Manufacturer & 18 & 13.7 & 15 & 3 & 1 \\
Car Company & 16 & 11.4 & 14 & 8 & 7 \\
Computer Parts Company & 16 & 7.0 & 9 & 0 & 1 \\
Transportation Department & 7 & 15.4 & 7 & 7 & 0 \\
\hline
\end{tabular}


Demographic information for participants in the Longitudinal Sample $(n=9)$

\begin{tabular}{|c|c|c|c|c|c|c|}
\hline Participant & Institution & Sex & URM & $\begin{array}{l}\text { Major reported in } \\
\text { junior year }\end{array}$ & $\begin{array}{l}\text { Reported } \\
\text { internships in } \\
\text { junior year }\end{array}$ & $\begin{array}{l}\text { Occupation } \\
\text { reported at } \\
\text { follow-up }\end{array}$ \\
\hline 1 & LPub & Female & Yes & $\begin{array}{l}\text { Civil and environmental } \\
\text { engineering }\end{array}$ & Yes & Structural engineer \\
\hline 2 & LPub & Male & No & Mechanical engineering & No & General engineer \\
\hline 3 & TPub & Male & No & Petroleum engineering & Yes & $\begin{array}{l}\text { Operations } \\
\text { engineer }\end{array}$ \\
\hline 4 & LPub & Male & No & Computer engineering & No & Software engineer \\
\hline 5 & TPub & Female & No & Chemical engineering & $\mathrm{n} / \mathrm{a}$ & $\begin{array}{l}\text { Production } \\
\text { engineer }\end{array}$ \\
\hline 6 & TPub & Female & No & Chemical engineering & Yes & Process engineer \\
\hline 7 & TPub & Female & Yes & Chemical engineering & No & Process engineer \\
\hline 8 & SPri & Male & No & Computer science & Yes & $\begin{array}{l}\text { User interface } \\
\text { engineer }\end{array}$ \\
\hline 9 & TPub & Male & Yes & Engineering physics & No & $\mathrm{R} \& \mathrm{D}$ engineer \\
\hline
\end{tabular}

Notes: LPub = Large Public University, SPri = Suburban Private University, TPub = Technical Public Institution, URM = Underrepresented minority (e.g., not white or Asian/Asian American), n/a = information not available.

ing after four years work experience. The sample consisted of nine engineers working in an engineering job at the time of the second interview: five from TPub, three from LPub, and one from SPri. The small sample notwithstanding, these interviews offer insight on how engineers' perceptions change over time, which we then seek to check with our Workplace Sample.

Table 4.2 displays demographic information for the Longitudinal Sample participants. Four of the nine were women, and four were from an underrepresented minority. Three were chemical engineering majors, two were computer-related majors, and the remainder ranged across other engineering disciplines. Four had held internships by their junior year. At the time of the interviews, one was enrolled in an engineering master's program and the other eight were working. Researchers interviewed the participants in person for approximately an hour when they were college juniors and on the phone for thirty to sixty minutes five years later. We examine first participants' answers to three questions asked when they were juniors in the spring of 2006:

- Are there particular skills that you would say are important for an engineer to have?

- Of the skills you mentioned, which ones do you possess and how did you develop them?

- In your own words, please define engineering.

We then focus on their answers to two questions posed during our follow-up interviews in spring 2011: 
- What knowledge and skills do you see as most important to doing your job?

- How has your idea of an engineering job changed since you graduated?

\subsection{Methodology of Interview Analysis}

We transcribed each set of interviews verbatim and made them anonymous. We then analyzed the interviews for each sample following a case study approach, with each participant representing a case (Creswell 1998; Miles and Huberman 1994; Stake 2006; Yin 2003). We used MAXQDA software to code the data. In this chapter, we use retrospective data from the Workplace Sample to identify how the knowledge and skills employed by young engineers diverged from what they learned in school. We combine the longitudinal data from the APS and the EPS to show how work altered the ideas about engineering held by participants as undergraduates. We then return to the Workplace Sample for further evidence on how young engineers' images of engineering changed since leaving school.

In the Workplace Sample, after coding each transcript, we combined mentions of different knowledge and skills into twenty-three distinct categories such as content knowledge and communication skills. We then clustered the categories into three broad types: technical knowledge and skills, professional knowledge and skills, and organizational knowledge and skills. In our analysis, knowledge relates to understanding or awareness of concepts, principles, and information related to a specific domain and skill to the ability to apply domain knowledge in a particular context. For instance, an engineer might have technical knowledge of how a machine works, but would use her technical skills to troubleshoot it. Technical knowledge and skills refers to competencies to accomplish specific engineering, mathematical, scientific, or computer-related tasks, such as technical problem solving, analysis, and design. In contrast, professional knowledge and skills are nontechnical competencies that relate to the profession of engineering and interaction with people more generally (Jarosz and Busch-Vishniac 2006, 243). Sometimes referred to as "soft" or "social" skills, professional knowledge and skills include teamwork, communication, and leadership skills (ABET 2011; Knight 2012; Shuman, Besterfield-Sacre, and McGourty 2005). Finally, organizational knowledge and skills relate to one's organization, work group, and job role that enables one to better navigate the work (Korte, Sheppard, and Jordan 2008; Korte 2009, 2010). ${ }^{6}$

We quantified the data using frequency counts and tables to describe the sample and identify patterns (Sandelowski, Voils, and Knafl 2009). For each skill and area of knowledge, we counted the percentage of participants who

6. See the appendix for definitions for each skill and area of knowledge. 
reported using it, the percentage of participants who reported learning it in school, and the percentage of participants who reported learning it (or continuing to learn it) on the job. We coded differences in the Workplace Sample's perceptions of school and work in the same way that we coded knowledge and skills, but we present these results in a more qualitative fashion.

In the Longitudinal Sample, we coded the interviews for the knowledge and skills respondents considered important to doing engineering work and for their ideas about what engineering entails. The longitudinal interviews were analyzed using the same inductive coding used for the Workplace Sample, but differ slightly since they are grounded in the language our informants used. Furthermore, because the Longitudinal Sample spans two sets of interviews, a consistent coding scheme was required across sets. For example, we grouped mentions of variations on problem-solving skills when participants were juniors and when they were four years beyond their bachelor's degrees under a single category. Skills and areas of knowledge mentioned only when participants were either juniors or young engineers are represented by their own categories. Each skill and area of knowledge is shown in the findings section and defined in the appendix. We also present qualitative results related to participants' changing perceptions of engineering work.

The two samples complement each other in giving the insights they provide into the "gaps" between engineering education and practice. The Workplace Sample of young engineers working for zero to three years in their first jobs after graduation helped us compare knowledge and skills engineers use at work with those learned in school. The Longitudinal Sample of early career engineers as college juniors and then as practitioners four years out offers a unique picture of changes in engineers' views of the work they do. Table 4.3 summarizes the way the surveys fit together in our analysis.

Table 4.3

Summary of Workplace and Longitudinal Samples

\begin{tabular}{lllll}
\hline Sample & Data source & Sample description & Sample scope & Main focus of study \\
\hline $\begin{array}{l}\text { Workplace } \\
\text { Sample }\end{array}$ & $\begin{array}{l}\text { APS } \\
\text { workplace } \\
\text { cohort }\end{array}$ & $\begin{array}{l}\text { Fifty-seven recently } \\
\text { graduated engineers, } \\
\text { zero to three years out } \\
\text { in } 2007\end{array}$ & $\begin{array}{l}\text { Four } \\
\text { organizations }\end{array}$ & $\begin{array}{l}\text { Where knowledge and } \\
\text { skills used at work are } \\
\text { learned (in school/on } \\
\text { the job) }\end{array}$ \\
$\begin{array}{l}\text { Longitudinal } \\
\text { Sample }\end{array}$ & $\begin{array}{l}\text { APS/EPS } \\
\text { longitudinal } \\
\text { cohort }\end{array}$ & $\begin{array}{l}\text { Nine early career } \\
\text { engineers: junior college } \\
\text { students in 2006 and } \\
\text { graduates four years out } \\
\text { in 2011 }\end{array}$ & $\begin{array}{l}\text { Three } \\
\text { institutions }\end{array}$ & $\begin{array}{l}\text { What knowledge and } \\
\text { skills are most } \\
\text { important to doing } \\
\text { engineering job }\end{array}$ \\
\hline
\end{tabular}

Note: APS = Academic Pathways Study; EPS = Engineering Pathways Study. 


\subsection{Findings}

\subsubsection{Knowledge and Skills in Engineering Practice (the Workplace Sample)}

The recently graduated engineers in the Workplace Sample identified the knowledge and skills that they applied on the job. Table 4.4 shows the number of participants who mentioned using technical knowledge and skills, professional knowledge and skills, and organizational knowledge and skills (defined in the appendix), as well as whether each of these was learned in $n=57$ )

\begin{tabular}{lccc}
\hline & $\begin{array}{c}\text { Percentage who } \\
\text { reported using } \\
\text { skill/knowledge } \\
\text { at work }\end{array}$ & & \multicolumn{2}{c}{$\begin{array}{c}\text { Percentage who reported } \\
\text { learning skill/knowledge }\end{array}$} \\
\cline { 3 - 5 } & In school & On the job \\
\hline Technical knowledge and skills $^{\mathrm{b}}$ & $\mathbf{9 8}$ & $\mathbf{9 3}$ & $\mathbf{8 6}$ \\
Content knowledge & 72 & 61 & 16 \\
Equipment/process knowledge & 60 & 5 & 60 \\
Problem-solving skills & 46 & 44 & 7 \\
Software skills & 39 & 33 & 26 \\
Modeling and analysis skills & 30 & 25 & 11 \\
Rapid iteration skills & 18 & 11 & 9 \\
Programming skills & 11 & 9 & 7 \\
Design skills & 11 & 7 & 4 \\
Testing skills & 11 & 4 & 7 \\
Systems-thinking skills & 5 & 5 & 0 \\
Hands-on skills & 4 & 4 & 2 \\
Professional skills & $\mathbf{9 6}$ & $\mathbf{5 3}$ & $\mathbf{9 6}$ \\
Communication skills & 65 & 25 & 58 \\
Working with people & 60 & 19 & 49 \\
Information-finding skills & 58 & 16 & 51 \\
Project management skills & 28 & 18 & 12 \\
Time management skills & 18 & 5 & 14 \\
Leadership skills & 12 & 5 & 7 \\
Documentation skills & 11 & 0 & 11 \\
Context knowledge & 9 & 0 & 9 \\
Work ethic & 5 & 0 & 5 \\
Organizational knowledge and skills & $\mathbf{6 7}$ & 76 & $\mathbf{5 6}$ \\
Organizational policies and procedures & 42 & 7 & 35 \\
Organizational hierarchy and structure & 28 & 28 & 9 \\
Organizational background and culture & 16 & & 7 \\
\hline
\end{tabular}

${ }^{a}$ All percentages are based on the total number of participants, $n=57$.

${ }^{b}$ Percentage of participants who reported using/learning at least one of the technical knowledge and skills listed in the table. The percentage of participants who reported using/learning professional knowledge and skills and the percentage of participants who reported using/ learning organizational knowledge can be interpreted similarly. 
school and/or on the job. As the table shows, virtually every participant reported using technical (98 percent) and professional (96 percent) knowledge and skills in their work, and most reported learning technical knowledge and skills in school (93 percent) and in the workplace ( 86 percent). But where they learned professional knowledge and skills differed. Just over half reported learning a professional skill or area of knowledge in school. Yet every engineer who mentioned professional knowledge and skills claimed to have mastered at least one of them at work. Additionally, only two-thirds reported relying on knowledge about their organization to do their work, which was learned almost entirely on the job (56 percent compared to 16 percent who reported exposure to this knowledge in school).

Although participants claimed to have acquired technical knowledge and skills from school as well as work, school was the more frequently mentioned source. Nearly three-quarters of the interviewees reported using content knowledge in their jobs, and 60 percent traced this knowledge back to courses ranging from basic physics and calculus to more advanced engineering topics (table 4.4). The advanced courses the participants viewed as relevant varied by discipline and by the companies for which they worked. Mechanical engineers at Car Company spoke of using what they learned in their engine courses, while their electrical engineering colleagues at $\mathrm{Car}$ Company relied more on their training in circuits. By contrast, only 16 percent of participants reported instances of content knowledge learned at work, typically around the engineer's particular job (e.g., traffic signal guidelines at Transportation Department; mechanical behavior of specific materials at Computer Parts Company).

School was also more important for learning how to solve problems and model and analyze data, with more than twice the number of participants reporting learning these skills in school than at work. With regard to problem solving, respondents felt their entire engineering education contributed to their ability to solve problems rather than any particular course or combination of courses:

There's definitely not a class on that [problem solving] by any means. It's more as you go through problems for homework and you work with your team members in labs, you just learn how to approach problems and come up with a solution. I wouldn't say it's something that people teach you at school. It's just something you pick up along the way. (Food Manufacturer, Chemical Engineering major, seventeen months on the job) ${ }^{7}$

With regard to learning software applications, participants reported that school and the workplace were more or less equally important. In fact, some engineers ended up deepening their knowledge of applications that they had

7. To assist the reader in interpreting our qualitative data, passages from interviews end with the organization where the participant worked or where he or she went to school, their undergraduate major, and the amount of time they had been either on the job or in/out of school. 
first encountered in a course. Nearly half of the engineers who learned to use a new software application on the job told us they had learned a simpler version in school, which made their learning curve less steep:

I've used different programs up at school. It just so happens that, in this job as a process engineer, we don't deal with those ones as much, but other ones. But just having the experience of using those programs, I was able to jump right into these new ones and get a feel for them. (Computer Parts Company, Mechanical Engineering major, nine months on the job)

In contrast, young engineers overwhelmingly reported learning about specific equipment and processes pertaining to their work on the job rather than at school. This result is expected given the diversity of jobs that engineers take and the limitations of engineering curricula to train for them all. The few participants who attributed their knowledge of a process to school cited learning about it in a particular course or an internship experience. Participants mentioned a variety of other technical skills, but with far less frequency: rapid iteration skills, programming skills, design skills, testing skills, systems-thinking skills, and hands-on skills. With the exception of testing skills, the young engineers told us they had learned these skills primarily or exclusively at school.

Most interviewees reported learning professional knowledge and skills on the job rather than in school, and most equated learning to be professional with acquiring communication skills, working with other people, and developing information-finding skills. While we present these skills as separate categories, they are highly related. Effective oral and written communication was the most commonly used professional skill cited by 65 percent of the engineers; while a quarter reported learning this skill in school, more than twice as many (58 percent) said they learned it on the job. For participants, learning to communicate effectively encompassed not only delivering better reports and presentations, but learning how to communicate with people who were not engineers (e.g., marketing, purchasing, sales, and client personnel).

Perhaps because three of the four employers were manufacturers, many participants reported needing to communicate with - and sometimes even manage - workers on the production floor, including foremen, machine operators, and maintenance workers. Others found they needed to communicate with contractors, suppliers, and customers. Learning to work with members of such groups was an eye-opening experience for many young engineers in which they discovered the importance of expressing themselves clearly, listening carefully, and getting to know them:

I learned a lot about making assumptions when it came to managing contractors. In one situation I had assumed that this contractor was capable of doing [a project], and it was a situation where basically that project didn't get done and had to be postponed. So, what I learned was the 
more information you can give them, the more successful you'll be. (Food Manufacturer, Chemical Engineering major, eight months on the job)

I learned that the people out on the floor are kind of the eyes and ears of the operation. They observe firsthand what's happening. So you better get to know them well and listen to what they have to say. Earning their respect is also important because if they don't think that you know what's going on, then they're going to have a hard time discussing their problems with you. (Computer Parts Company, Mechanical Engineering major, seven months on the job)

Working with other people was another important professional skill that young engineers reported they learned mostly on the job. Many considered having good interpersonal skills to mean getting to know coworkers or supervisors personally, establishing relationships with them, networking to gain visibility and identify key resources, and being able to convince collaborators of their ideas.

I've learned where people's strengths are. Some people are really detail oriented, so if I have a detail-oriented question, I'll go to them. Some people are better communicators. And there are people that know their stuff but when they try and explain it to you, I'm just like, "You're not even understanding my question." So I've sort of flagged those people in my mind. (Computer Parts Company, Chemical Engineering major, eight months on the job)

[I learned] that you've really got to network and get to know people on a personal level and earn their respect and respect them. It's really different around here because no one has to do anything. If you want people to go outside of the box to help you, you've got to [get to] know them. (Car Company, Mechanical Engineering major, twelve months on the job)

On the job, young engineers also acquired tips on good group work practices such as following up emails with face-to-face or phone conversations, requesting that deliverables be sent by a certain date, and checking on the status of deliverables at regular intervals. Several mentioned learning to keep others updated on the status of their own deliverables, since it prevented conflict and made it easier to locate help when problems occurred:

I learned that you've always got to check up on people and make sure that they have it [their deliverable] done in a week or so of what they said. You want to rely that they're going to do what they say they're going to do but you really can't. So you've always got to double check behind someone to make sure that he's doing exactly what they asked. (Car Company, Mechanical Engineering major, four months on the job)

I guess it's best to keep everyone in the loop always. Send out mass emails to try to keep everyone in the loop, so then there isn't questioning. Everyone knows where you're at with it, and then if they have an idea, they 
can throw it out and you can try that idea too. (Computer Parts Company,

Mechanical Engineering major, seven months on the job)

Young engineers also reported having to learn information-finding skills on the job. For a few, information finding meant becoming familiar with using their organization's databases, but, as Korte (2009) documented, many more discovered that their coworkers were the most significant source of information. Some interviewees spoke of specific strategies for seeking help, such as first building camaraderie with their coworkers and then making sure not to monopolize their coworkers' time. Other professional knowledge and skills young engineers used in their work included project management skills, time-management skills, leadership skills, documentation skills, context knowledge, and a work ethic. Participants learned all but project management skills primarily or exclusively in the workplace.

Two-thirds of the participants reported applying knowledge about their organization in their technical work. A majority of those who applied this knowledge reported learning this organizational knowledge on the job (56 percent), although some (16 percent) reported acquiring the knowledge as students, particularly during internship and co-op experiences. Among all who mentioned knowledge about their organization, over 40 percent equated this knowledge with routine or bureaucratic procedures, specific policies, and procedures that they had learned (for example, how to write test protocols or submit work orders). By contrast, only 16 percent talked about the organization's background or culture. Just over a quarter said they had developed an understanding of the hierarchy or division of labor, including how different departments worked together and what role the various departments played in the bigger picture.

Indicative of the company-specific nature of organizational knowledge, only a quarter of participants who had internships mentioned what they had learned about their organizations or life in their organizations during that time, and few reported transferring that knowledge to their current job. In most cases, it was not until the interviewer asked them about what they had learned about organizational knowledge from their internships that they spoke of this topic. Perhaps these young engineers were aware of their organizations and how they operated but did not consciously apply that knowledge in their work. Our asking participants about knowledge and skills they used while doing specific tasks may have also focused their responses away from what they learned in other work settings. But some engineers did report learning about how organizations work in an internship and applying that knowledge in their work, even if they had interned with a different employer than their current one. This suggests that lessons from working in one professional engineering environment may transfer to others.

In sum, engineers reported early in their careers employing a variety of 
technical, professional, and organizational knowledge and skills. Technical work required knowledge of specific content, tasks, and processes, as well as general problem-solving skills. Professional work involved communicating with many different groups of people, as well as interpersonal, relational, and information-finding skills. Organizational work included understanding the culture, values, and operating procedures of their organization. Although these young engineers had developed strong technical backgrounds in school, which they expanded and refined at work, they learned most of their professional knowledge and skills, as well as their organizational knowledge and skills, at work. Additionally, although they might have gained some professional and organizational knowledge and skills through their internship or co-op experiences, most could not explicitly connect this to their technical work. The findings suggest that engineering graduates might benefit from better instruction in the professional and organizational aspects of their work while in school.

\subsubsection{Changing Views of Engineering Practice (the Longitudinal Sample)}

Comparing the knowledge and skills that engineers thought were important when they were college juniors with those they thought were important after four years on the job provides a sense of how engineers' perceptions change as they move from being students to being practitioners. Table 4.5 shows the number of Longitudinal Sample participants who mentioned various technical and professional skills or areas of knowledge at both points in time.

Table 4.5 shows that participants' impressions of the general importance of professional knowledge and skills remained relatively constant over time, but the relative importance of technical knowledge and skills declined with twenty fewer mentions after working for four years. Respondent engineers were less likely to mention math, logic, science, problem-solving, and visualization skills as crucial for their work. They were just as likely to mention content knowledge and software skills, and like engineers in the Workplace Sample, provided specific examples of knowledge and applications once in a job. The pattern suggests that engineering students may mistakenly overemphasize the relevance of broad (versus specific) technical knowledge and skills to engineering practice.

This supposition is supported by responses that interviewees gave when asked to define engineering as students. Seven described engineering as problem solving, and three explicitly emphasized that engineering entailed the application of math and science.

Engineering is the applied use of science and technology to solve problems. (Technical Public Institution, Engineering Physics major, junior year) 
Table 4.5

Comparison of important knowledge and skills (Longitudinal Sample, $n=9)$

\begin{tabular}{lccc}
\hline & \multicolumn{3}{c}{$\begin{array}{c}\text { Number of participants who reported skill/ } \\
\text { knowledge as important }\end{array}$} \\
\cline { 2 - 4 } & $\begin{array}{c}\text { Junior year } \\
\text { of college }\end{array}$ & $\begin{array}{c}\text { Four years } \\
\text { postgraduation }\end{array}$ & Difference \\
\hline Technical knowledge and skills & $\mathbf{9}$ & $\mathbf{6}$ & $\mathbf{- 3}$ \\
Math skills & 8 & 1 & -7 \\
Logic skills & 5 & 0 & -5 \\
Science skills & 4 & 0 & -4 \\
Problem-solving skills & 3 & 2 & -1 \\
Technical skills (general) & 2 & 1 & -1 \\
Visualization skills & 1 & 0 & -1 \\
Content knowledge & 2 & 2 & 0 \\
Software skills & 1 & 1 & 0 \\
Total no. mentions & 26 & 6 & -20 \\
Professional knowledge and skills & $\mathbf{8}$ & 7 & $-\mathbf{1}$ \\
Context knowledge & 3 & 0 & -3 \\
Creativity skills & 3 & 0 & -3 \\
Teamwork skills & 2 & 0 & -2 \\
Social skills (general) & 1 & 0 & -1 \\
Self-directed learning skills & 1 & 1 & 0 \\
Business knowledge & 0 & 1 & +1 \\
Documentation skills & 0 & 1 & +1 \\
Self-motivation skills & 0 & 1 & +1 \\
Working with people & 1 & 3 & +2 \\
Communication skills & 2 & 5 & +3 \\
Total no. mentions & 13 & 12 & -1 \\
\hline
\end{tabular}

${ }^{a}$ Number of participants who reported using/learning at least one of the technical knowledge and skills listed in the table. The number of participants who reported using/learning professional knowledge and skills can be interpreted similarly.

Engineering is the art of figuring out interesting problems that need to be figured out using math and science. (Suburban Private University, Computer Science major, junior year)

Engineering is just coming up with solutions to problems using math and science. (Technical Public Institution, Petroleum Engineering major, junior year)

Furthermore, when asked as students where they learned the knowledge and skills they considered important, the participants said they learned math and science in the classes they had been taking since elementary school. A few mentioned teachers that had encouraged them to pursue engineering because of their abilities in science and math. Thus, the students' images of engineering revolved around technical knowledge and skills by its link to math and science in school. 
My childhood was pretty exposed to gaining those types of skills. My father was an accountant so his math background helped a lot. As far as grade school, I always had teachers that were supportive with math and science in general. So I was kind of encouraged in that area. (Large Public University, Computer Engineering major, junior year)

By contrast, when students said they learned nontechnical knowledge and skills, the learning was linked to experiences outside of school, such as extracurricular activities and sports.

Being social is easy for me. I'm involved in a whole bunch of different things on campus that allows me to get out there and meet new people. That's how I developed that one [social skills]. (Large Public University, Civil and Environmental Engineering major, junior year)

The findings also suggest that even though participants ascribed some importance to professional knowledge and skills when they were students, they were not attuned to those most needed in practice. As students, the engineers thought teamwork skills, context knowledge, and creativity skills were most important. Knowledge and skills such as communication and working with people were deemed more valuable four years later, when mentions of these two skills more than doubled. The meaning of these skills also changed from very general communication and teamwork skills as juniors to interacting with people within and outside their work group as working engineers. This change is consistent with the evidence from the Workplace Sample in which young engineers spoke of needing to work with different groups of people, but not necessarily in teams. This could be another case of students aligning their beliefs of what is important to engineering practice with what they experienced in the classroom. Or, to put it differently, engineering programs may overemphasize teamwork skills and underemphasize communication skills, especially the ability to communicate with people from different positions, disciplines, and even walks of life.

I work with a lot of different groups of people, and I communicate with a lot of different types of people, and the way that I communicate with my operators is very different than the way that I communicate with the engineers that I work with, just because of their level of education and understanding of certain things. (Technical Public Institution, Chemical Engineering major, four years postgraduation)

I have to communicate recommendations and changes to a wide variety of people, from people with engineering experience in my own group to operators who have a high school education to operating management. So being able to communicate to a wide array of people is very important. (Technical Public Institution, Chemical Engineering major, four years postgraduation)

Nevertheless, despite many similarities, participants in the Workplace Sample and in the Longitudinal Sample had somewhat different opinions of 
the knowledge and skills that engineers require. Participants in the Longitudinal Sample did not mention specific job tasks and processes, informationfinding skills, or knowledge about their organizations. Perhaps this reflects the fact that the studies framed the issue differently; the workplace study asked engineers about task-specific knowledge and skills used to work on a particular project or problem, while the longitudinal study asked about metaskills important to their work in general. Alternately, participants in the Workplace Sample spoke about knowledge and skills used in the first couple of years at work, while longitudinal participants spoke about knowledge and skills at two very different points in their career. The two groups of engineers could have differed in what knowledge and skills were important because participants in the Longitudinal Sample had been working longer than participants in the Workplace Sample. As engineers work longer, they might move into less technical roles with broader scope. Some knowledge and skills may become less important to engineers' work, causing these aspects of the work to recede into the background.

Strikingly, no engineer in the Longitudinal Sample specifically identified project management skills as important, either as students or after four years on the job. Yet, when asked whether their idea of an engineering job had changed since they graduated, six of the nine participants said that they had not realized their work would include project management including such tasks as dealing with people, attending meetings, writing documents, and creating schedules and budgets. Given the high frequency with which some interviewees performed these tasks, it is unclear why they did not identify project management skills as important. One possible reason is that they did not perceive project management to be "real engineering," a finding corroborated by the Workplace Sample. With regard to how their idea of an engineering job had changed, two longitudinal participants replied:

There are parts of the job that I don't think make use of my engineering skills but I think are necessary for the role that I'm in, things like writing procedures. I don't think that's necessarily what I would call an engineering task, but sometimes it's necessary just because I'm the one with the knowledge required to write that procedure. (Technical Public Institution, Chemical Engineering major, four years postgraduation)

I think a lot of it [work] can be time management and dealing with people. But as far as strict engineering like what we were taught in school-calculations and stuff like that - it's a lot of fun but it doesn't take up the majority of my day. (Technical Public Institution, Petroleum Engineering major, four years postgraduation)

Further analysis of our interviews with the Longitudinal Sample suggests that students may have unrealistic or distorted views of engineering. As students, participants saw engineering education and practice as primarily 
technical, and had overly narrow perceptions of the professional aspects of engineering. Some of their misconceptions appear to remain with them into the workplace, influencing their views of their jobs. To the degree that students either choose or do not choose engineering as a profession because of these views, the profession has a problem. Moreover, those who choose engineering may not be taking advantage of opportunities at school that would make them better engineers at work.

\subsubsection{Changing Expectations for Engineering Practice (the Workplace Sample, Revisited)}

With the changes in how our longitudinal participants perceived engineering in mind, we return to the Workplace Sample to compare students' expectations for professional practice with the realities they faced as new hires. We asked the fifty-seven engineers in the Workplace Sample to tell us how engineering practice differed from the expectations they had when they were in school. Some claimed there were no differences and that their classes, extracurricular activities, and internships had well prepared them for work. A few considered school and work to be similar, since both required using the same tools and concepts to solve problems:

I would say [school is similar] in that you're given a problem and left to go from there. You've got to figure out what exactly you need to do, how you're going to go about doing it, and then get the results and look at them and figure out if they are good. I feel like that's similar to the work here. (Car Company, Mechanical Engineering major, fifteen months on the job)

It's easier to answer how they're [school and work] the same, actually. I don't use the equations for almost anything anymore, but I understand the concepts and I use those all the time. (Computer Parts Company, Mechanical Engineering major, eight months on the job)

More, however, noted differences, as we have pointed out in prior writings; for example, engineers' work emphasizes application while school emphasizes theory, problems at work have greater scale and complexity, and at work, engineers need to seek out information actively on their own (Korte, Sheppard, and Jordan 2008; Brunhaver et al. 2010). Particularly telling is that young engineers quickly learned that professional practice requires more social interaction than technical work, and that it is more cross-disciplinary than school led them to appreciate.

Of the twenty-nine participants who said that engineering work was more social than technical, sixteen admitted being surprised by this. Prior to starting their jobs, they expected primarily technical work. For some, this meant spending considerable time doing design or analysis. Others expected to use the equations and theories learned in school. But once on the job our interviewees reported spending more time than they expected managing people, 
helping to troubleshoot equipment, and working on the production floor. For those who had expected to work alone, the reality was difficult to accept:

Yeah, that [doing more technical work] was my expectation and that's why I chose to be a civil engineer. I just want to do technical work and don't [want to] deal with people and management. (Transportation Department, Civil Engineering major, twelve months on the job)

I think there's a lot of disillusion once you leave engineering school, because when you're there, you're taking all these tests, you're doing all these math problems, and you're delving deep into theories and equations and formulas, and I haven't touched any of that stuff in the year and half that I've been here. (Food Manufacturer, Chemical Engineering major, seventeen months on the job)

Some of the young engineers had theories as to why their work was so different. One believed that his or her organization had already solved all of the hard problems and now only needed engineers to verify the results.

Engineering here seems less technical at times because the company is established and the processes have been established. There's already been a lot of testing. So we have learned everything. I'm dealing a lot more with tests now, verifying I guess what the computer programs are getting out. (Computer Parts Company, Mechanical Engineering major, nine months on the job)

Another believed that their organization outsourced technical work to save time and money.

What I learned was that we typically, at least at this plant, don't do so much [design]. We are resource limited, so rather than spend our time trying to figure things out, you know, "I need a two-inch pipe," we farm that out to an outside vendor. (Food Manufacturer, Chemical Engineering major, seventeen months on the job)

Still others thought the amount of technical work varied widely by position, and that even though they were not doing as much technical work, some of their coworkers could be. Besides, no matter how technical the job, engineering work would always involve some social interaction.

There's technical [work] and project management, but in the particular role I'm in now, it's more project management than it is technical. And you'll find that within [organization], it depends on the position that you're in. (Transportation Department, Civil Engineering major, thirtysix months on the job)

Yeah, there are some places you can go technical. But there is nothing that's centrally technical. There has to be communication, you have to work with people. I think that's the major thing I learned when I started at [organization]. (Transportation Department, Civil Engineering major, twelve months on the job) 
Sixteen participants said engineering work required them to reach beyond the discipline they studied in school. Four of the sixteen were not surprised. Even in school they had expected to be primarily general problem solvers and only secondarily, disciplinary experts.

I was studying to be an electrical engineer, but [I learned] I was going to be an engineer first, and then an electrical engineer. Engineering has to do with solving problems, making requirements, stuff like that. I learned that that's how engineering was going to be, and I've come to the conclusion that, yes, that's how it is. (Car Company, Electrical Engineering major, five months on the job)

The other twelve were surprised their employer made them responsible for projects outside their expertise. At Car Company a few mechanical engineers found themselves doing electrical or computer engineering-related work. Similarly, chemical engineers at Food Manufacturer and Computer Parts Company became involved in mechanical and civil engineering-related work. Some interviewees found the differences between their work and the discipline they studied to be nuanced, but others, like the chemical engineers at Food Manufacturer and Computer Parts Company, were not working with any of the processes or equipment learned in school and felt thrown into a completely different field:

I would have never guessed that I'd be making circuits. I never thought about how the chemical engineering process can be applied in that type of scenario. This company does not have actual chemical engineering processes. I wasn't really expecting [that] big a contrast. (Computer Parts Company, Chemical Engineering major, six months on the job)

Overall the reflections of the engineers in the Workplace Sample suggest that engineering work is much more variable, complex, and social than most engineering curricula convey. The picture is consistent with the other data we have discussed. A young engineer's work is less about using theories or equations than about project management and working with other people. Engineering practice is not confined to a single area of expertise. Instead, it requires young engineers to pick up new knowledge and skills on the job. Given the reported gap between work and education, it seems reasonable to suggest that engineering programs and engineering practice be reconfigured to achieve closer alignment between school and work. We elaborate on this idea next.

\subsection{Summary and Implications}

Our interviews with early career engineers in the Workplace and Longitudinal Samples point to two distinct but interrelated sides of engineering practice: the technical and professional sides. In addition to technical work, young engineers are responsible for nontechnical tasks that require signifi- 
cant social interaction, such as managing projects and coordinating the work of other people. Employers also expect young engineers to be able to work outside the specific discipline in which they trained and to work with people who were not engineers.

Despite these realities, engineering students emerge from their programs with relatively narrow views of professional practice. Although students may ascribe some importance to nontechnical skills, they mainly conceive of engineering as technical problem solving involving the direct application of theory and equations they learned in classes. Students develop these conceptions in part by looking at their teachers and college professors. Most respondents in a recent survey of $\mathrm{K}-12$ educators associated engineering with math, science, and making and fixing things (Yasar et al. 2006) while Pawley (2009) showed that engineering faculty described their profession in much the same way. Given that students learn and internalize these messages as early as elementary school (Capobianco et al. 2011; Cunningham, Lachapelle, and Lindgren-Streicher 2005; Oware, Capobianco, and Diefes-Dux 2007), it is not surprising that they persist beyond formal schooling.

To be sure, the data indicate that the technical knowledge and skills that students learn in school are indeed important to engineering practice. Furthermore, most young engineers continue to refine and expand their knowledge and skills after starting work. This later learning, however, focuses primarily on the doing of a specific job. Once on the job, the importance of technical knowledge and skills appears to decline. Many engineers in the Workplace Sample even noted the lower importance of these competencies from the start.

But as technical knowledge and skills become less central or less sufficient for doing engineering work, the importance of professional knowledge and skills increases. Even when students are exposed to the professional side of engineering work in school, they may not fully grasp what this work looks like on the ground. This seems particularly true for communication and teamwork. Although some students think that communication skills are important to engineering, it is only after they start working that they begin to speak explicitly about the value of formal (technical reports and oral presentations) and informal (e.g., interacting with others via phone and email) communication on the job. Similarly, students readily talk about the importance of working in teams, but none of our young, employed engineers described teamwork in the manner typically found in engineering programs (Colbeck, Campbell, and Bjorklund 2000). Instead, they spoke of working and communicating with different groups of people, including other engineers, operators, managers, clients, and suppliers. This discrepancy is systemic of a larger issue in engineering education in which faculty lack the time, resources, and incentives to create multidisciplinary experiences within 
the current disciplinary structure (Jamieson and Lohmann 2009; McNair et al. 2011). ${ }^{8}$

The data show that once on the job, young engineers' appreciation of professional knowledge and skills becomes more nuanced. Yet, engineers are still apt to consider less technical work, such as project management, to differ from "real engineering" and not to be directly related to their degrees. Going forward, outsourcing and automation will likely make project management a common position for engineering graduates. Since students expect synergy between "what is learned in [the] classroom and what is needed in the field for successful practice" (Steering Committee of the National Engineering Education Research Colloquies 2006, 259), this affects how engineers value their education. Finally, two-thirds of the engineers in the Workplace Sample mentioned knowledge they had learned about their organizations in order to do their jobs. However, most participants failed to see connections between this knowledge and their technical work on their own. Few of those who had held undergraduate internship or co-op experiences could transfer lessons they had learned then to their current work situations now. These findings substantiate employers' low ratings of engineering graduates in the area of organizational contexts and constraints (see introduction; Lattuca, Terenzini, and Volkwein 2006). It is also puzzling that none of the participants in the Longitudinal Sample mentioned knowledge about their organization as important, especially since knowing how an organization operates and how to successfully negotiate hierarchies, divisions of labor, and status structures are critical for success in almost any organization. We suspect, however, that young engineers fail to mention organizational policies and processes because they do not see them as a form of knowledge unless explicitly cued to do so.

Our findings are consistent with and extend prior studies of engineering education. ${ }^{9}$ Salzman (2007) reported that because managers find technical skills to be common, they cannot use them to distinguish between job can-

8. Notwithstanding the recent focus on such teamwork (ABET 2011; National Academy of Engineering 2004), most group work is done in students' own disciplines, and few faculty members have experience or training in managing groups (Colbeck, Campbell, and Bjorklund 2000).

9. Bucciarelli and Kuhn (1997) argued that formal education prepares engineers to succeed in the "object world" (211) but overlooks the process-oriented, context-laden social world. Based on a study of engineers in a large high-tech company, Perlow and Bailyn (1997) not only concurred with Bucciarelli and Kuhn's assessment, but added that engineers typically perceive "real engineering" to pertain only to the object world. Through semistructured interviews with a broad sample of engineers, Trevelyan $(2009,2010)$ found that most engineering curricula focus solely to the technical aspects of engineering even though engineering is both a technical and social discipline. Similarly, Sheppard et al. (2008) described engineering as interactive and complex work that encompasses many domains beyond the technical. Sheppard et al. also found such an image of engineering contrasted sharply with the narrow way that most engineering education is currently framed. 
didates. Managers seek young engineers who possess nontechnical skills, especially communication skills and the ability to work across "borders," both disciplinary and organizational. Yet, these skills are often the most difficult for the managers to find in new engineers (Salzman and Lynn 2010; Lattuca, Terenzini, and Volkwein 2006).

These studies point to deficiencies in the current model of engineering education that constrains it from producing engineers with knowledge and skills required for being effective in the workforce and suggests the value of elevating professional and organizational knowledge and skills in training engineers. Complicating such a change is the fact that most engineering programs are burdened by a crowded curriculum, which makes adding content a challenge (Jamieson and Lohmann 2009; Salzman and Lynn 2010; Trevelyan 2007). Moreover, because cutting edge technical training is central in engineering education, any redesign of engineering pedagogy, assessment, and accreditation to connect education with practice will have to find ways to integrate professional and organizational knowledge and skills with training in the latest engineering concepts and tools (Froyd and Ohland 2005; Litzinger et al. 2011; Sheppard et al. 2008).

\subsubsection{Implications for Engineering Education}

To develop competent and productive graduates, engineering schools should consider ways to emphasize the professional and organizational content as well as technical skills — not only in the classroom but in cocurricular and extracurricular activities as well. Many engineering students hold the unrealistic view that engineering is synonymous with technical problem solving even after they have completed design projects (such as senior capstone) in upper-division courses. Given how resistant to change the image of engineering as solely technical seems to be, engineering schools should seek ways to help students connect their early experiences in math and science to later engineering experiences and, ultimately, to professional practice. Providing opportunities to learn about real engineering work at every stage of an undergraduate career or even as part of $\mathrm{K}-12$ education could potentially improve the attractiveness of engineering as a career. One way to accomplish this goal would be through cognitive apprenticeships (Collins, Brown, and Holum 1991; Sheppard et al. 2008) that expose students to professional practice through carefully staged and monitored steps. In this approach, educators first model expert practice; then, they scaffold students' efforts to imitate their performance, providing feedback where needed. The process is repeated over time, moving from simple lab and design exercises in the students' freshman year to closer "approximations of practice" (Grossman et al. 2005) by their senior year. ${ }^{10}$

10. Other ways to expose students to real engineering include pedagogies designed to help students make sense of and develop the abilities for practice. Examples include design tasks 
Because engineering graduates work with a wide variety of people including nonengineers, collaborative and cooperative learning, which emphasize small group work, are particularly promising (Johnson, Johnson, and Smith 1998; Prince 2004; Smith et al. 2005) especially when the groups are demographically and disciplinarily heterogeneous so that students learn how to work with people who are different from themselves (Colbeck, Campbell, and Bjorklund 2000; McNair et al. 2011). Similarly, students could be required to take courses in other departments to prepare for multidisciplinary products and projects in the workplace and engineering programs and schools could support faculty to make this happen (Jamieson and Lohmann 2009; McNair et al. 2011).

Engineering students also need to learn to communicate their ideas to a variety of audiences and in many modes. For this objective, project-based learning may be particularly useful (Dym et al. 2005). When implemented in teams, projects allow students to practice formal communication via technical reports and oral presentations as well as informal communication through email, memoranda, group meetings, and so on. Projects also expose students to other professional knowledge and skills including the management of tasks, schedules, and people. Finally, engineering graduates must be able to direct their own learning when they recognize they do not know something. Problem-based learning requires students to formulate their own problems and then find information for solving the problems (Prince 2004; Woods 1994). Students also need to begin becoming savvy about organizations while in school. Given the wide range of paths that students eventually pursue, no curriculum can address every detail of an organization's history, culture, policies, and procedures, but it is possible to expose students to a variety of organizational systems through field trips, case studies, and in-class speakers and to design assignments to emphasize workplace contexts and constraints that mimic those that students might encounter. Engineering students could be encouraged to take courses in organizational behavior and other related topics. Even technicalengineering courses could include a stronger emphasis on the organizational and contextual influences that affect the practice of engineering.

Engineering students might benefit from opportunities to learn about professional practice outside the classroom. Venues for doing so would include research experiences, study abroad, involvement in professional societies, internships, co-ops, and other forms of employment. Internships and co-op experiences provide firsthand insight into what engineers really do and how they use the knowledge and skills they learned in school and a head start on

and laboratory work (Litzinger et al. 2011; Sheppard et al. 2009). More recently, educators and researchers have experimented with other methods such as portfolios (Dunsmore, Turns, and Yellin 2011; Eliot and Turns 2011) and think-aloud protocols (Douglas et al. 2012). Given their emphasis on the social, these latter examples may be especially effective for teaching professional and organizational knowledge and skills. 
developing a professional network. Students who participate in internships and co-ops are better prepared for the workplace and, thus, more employable (Haag, Guilbeau, and Goble 2006). Internships and co-ops may also help students more knowledgably choose an engineering discipline or decide whether to pursue an engineering career (Raelin et al. 2011). Engineering programs could also actively help students reflect on and integrate these experiences into their understanding of engineering practice.

Incorporating such changes into a four-year engineering curriculum will not be easy. Some academicians, organizations, and even some students have called for either extending the engineering bachelor's degree to five years or making the master's degree the first professional engineering degree to attain a more equal balance of theory and practice (National Academy of Engineering 2005; Grose 2012). Revising engineering curricula may require considering how to redesign traditional courses to more closely align with practice or by building consensus on what conceptual and theoretical knowledge is more relevant for practice.

Other stakeholders can also help tighten the connection between schooling and work (Korte 2009; Sheppard et al. 2008). Firms can partner with engineering schools to assist in redesigning programs and developing ways for students and practitioners to interact inside and outside of the classroom. Practicing engineers might deliver guest lectures, coach students, provide program feedback, and serve as adjunct faculty. Firms and trade associations can sponsor fieldtrips, design projects, internships, and co-ops and can sponsor educational innovation and scholarship both in the university and industry (Jamieson and Lohmann 2009). National research, accrediting, and professional organizations play a vital role in advocating for educational reform. They promote and reward engineering programs and faculty dedicated to experimenting with innovative pedagogies, and endorse best practices through assessment and accreditation, and thus could help engineering schools become more practice oriented (Sheppard et al. 2008).

Finally, our study and others suggests that, much like collegiate engineering programs, $\mathrm{K}-12$ education tends to emphasize the importance of math and science to engineering. Others have argued that primary and secondary schools are neither teaching the right knowledge and skills nor sending the right messages to students about engineering (National Academy of Engineering and National Research Council 2009; Anderson et al. 2011; Capobianco et al. 2011). For example, $\mathrm{K}-12$ students often believe that engineering is sedentary work that involves little interaction with people (National Academy of Engineering 2008a); K-12 educators who expose students to images of how engineers use their skills could also reduce stereotypes that students have about engineering as well. 


\subsubsection{Implications for Engineering Practice}

Industry can help young engineers adjust more effectively to the transition from school to work. Particularly helpful would be information at the point of hiring, if not sooner, about the kind of work a student will be doing. During the first few months of a job, discussions of the employer's culture, history, policies, and procedures could be contextualized so that new recruits can envision how these factors will influence their work. Young engineers would benefit if managers and coworkers served as mentors to help them see how the knowledge and skills that they learned in school apply to their jobs, particularly if they will be doing project management (Korte 2009, 2010). Coaching and mentoring enhances internships and co-op experiences by giving students exposure to diverse people and organizational settings and more realistic job previews (Parsons, Caylor, and Simmons 2005; Raelin et al. 2011).

To achieve these objectives, employers need to better understand the work that they hire young engineers to do, so that they can set their own expectations appropriately. In many firms, a bachelor's degree is a requirement for practice, yet some engineering jobs can be adequately filled by workers with an associate's degree. Employers could ask whether they are properly utilizing their young engineers and whether these individuals are capable of doing more complex and creative work. If the latter is true, then the young engineers' roles and responsibilities need to be adjusted so that they can contribute more to the organization and pursue meaningful work. Employers can collaborate more closely and meaningfully with engineering educators and researchers so that engineering curricula can be improved.

Perhaps most troubling for the profession is that some students may turn away from engineering careers because they have a limited understanding of what engineering is or because how it makes use of the knowledge and skills they value (Atman et al. 2010; Lichtenstein et al. 2009). For students confident in their communication and interpersonal skills, realizing that engineering involves a significant amount of social interaction may make engineering more attractive. Students without this confidence may find engineering less attractive. When asked how her idea of an engineering job had changed since graduation, one interviewee remarked, "I'm just seeing more of the opportunities I didn't even know existed when I was in school" (Technical Public Institution, Chemical Engineering, four years postgraduation).

\subsubsection{Implications for Future Research}

Additional research is needed on how engineering students' concepts of engineering work affect their careers and to what extent our finding that, over the first four years of employment or practice, the importance of general technical knowledge and skills in engineers' work wanes while the importance of professional and organizational knowledge and skills rises due to 
the role of shifts in engineers' work responsibilities or in their perceptions of shifts. Further study is also needed into how the nature of engineering work varies depending on the type of organization or project. Larger data sets can help, for example, determine the influence of organizational size or industry sector, or of engineering discipline and institution type. Our longitudinal study may also be expanded to capture how engineers' views change over a longer period of time. Our identifying organizational knowledge as an important competency for young engineers suggests the value of further research into the role of such knowledge and how engineers attain it in career development. ${ }^{11}$

Finally, the gaps between engineering education and practice that we have analyzed mirror similar gaps found in nursing, medicine, business, law, accounting, and teaching (Colby et al. 2011; Cooke, Irby, and O'Brien 2010; Jones 2002; Sullivan et al. 2007). Like engineering, programs in these professions struggle with the integration of professional knowledge and skills with technical content. Too often, the gap between what university programs teach and what employers want can also be seen as a divergence between what education provides and what firms provide. ${ }^{12}$ Both education and industry could improve the fit by working out together their expectations for graduates and what their respective roles and responsibilities will be, with a strong involvement of students. That there are gaps between professional training and work not only in engineering but in other key professions suggests the value of future research on the experiences of professional training and work more broadly, from which engineering and the other professions can gain.

11. In our Workplace Sample, many spoke of not understanding how their work fit into the organization or not knowing what they needed to know (Brunhaver et al. 2010; Korte, Sheppard, and Jordan 2008).

12. According to Cappelli (2007) the real reason is that employers no longer provide the internal training needed to develop the skills of new hires, seeking instead new hires who can "step immediately into the job and start doing the work" (Center for Education 2008, 67), and for educators policymakers to take on the responsibility for training that they have shouldered in the past. While controversial (Center for Education 2008), these comments set the stage for a discussion between the university and industry. 


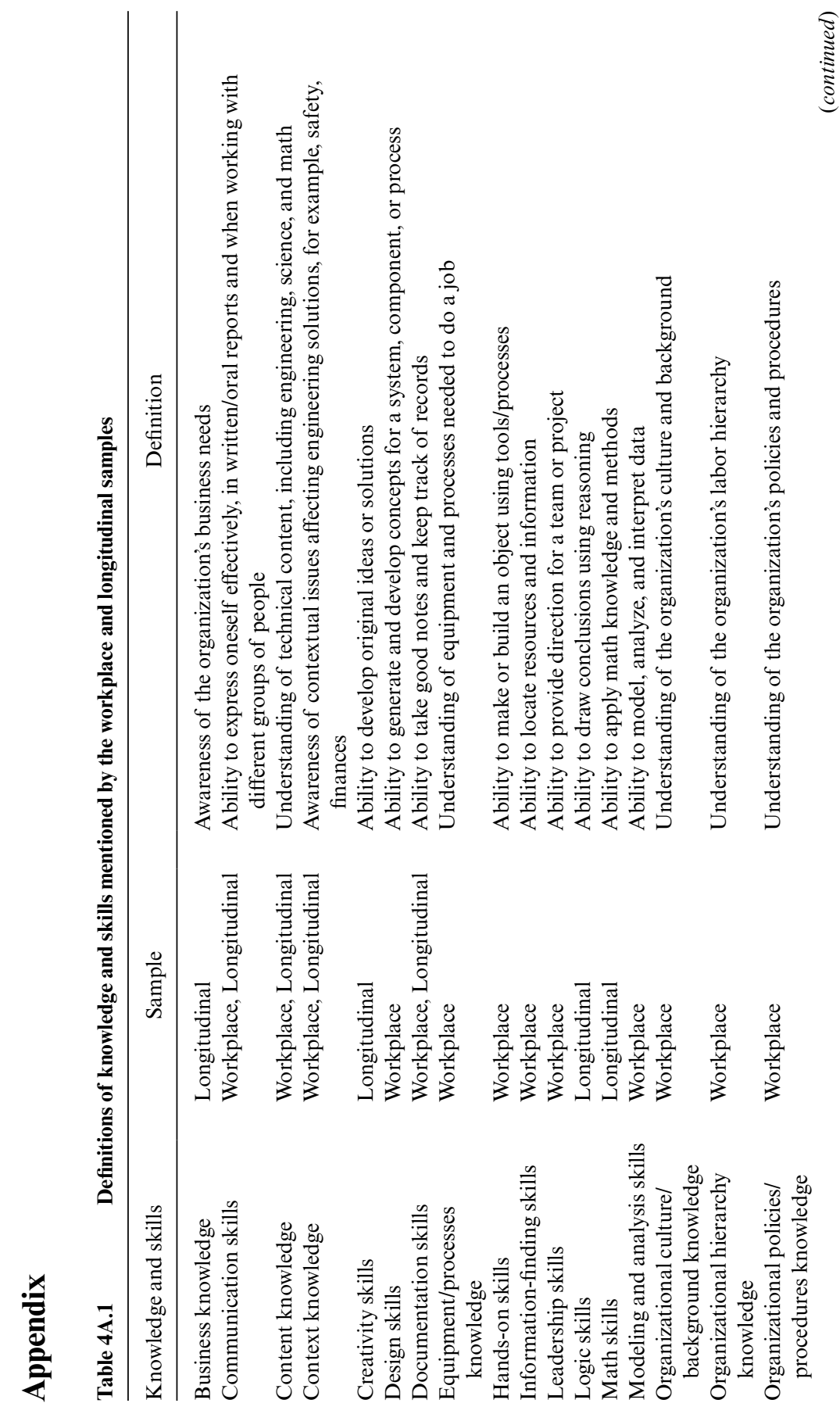




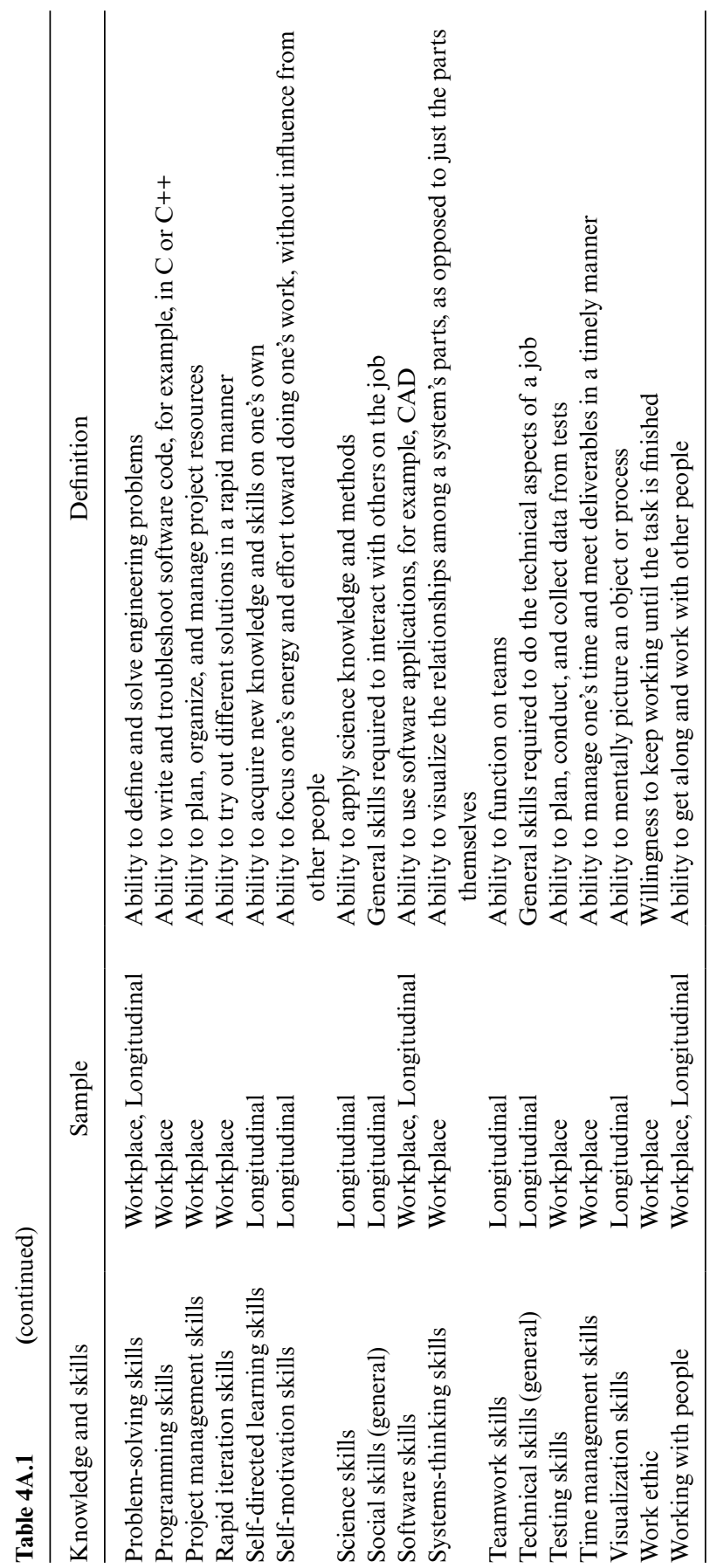




\section{References}

ABET. 2011. Criteria for Accrediting Engineering Programs. Accessed Sept. 1, 2012. http://www.abet.org/wp-content/uploads/2015/04/appm-2010-2011.pdf.

American Society of Civil Engineers. 2008. Civil Engineering Body of Knowledge for the Twenty-First Century: Preparing the Civil Engineer for the Future, 2nd ed. Reston, VA: American Society of Civil Engineers.

Anderson, Kevin, Sandra Courter, Thomas McGlamery, Traci Nathans-Kelly, and Christine Nicometo. 2009. "Understanding the Current Work and Values of Professional Engineers: Implications for Engineering Education." Proceedings of the American Society for Engineering Education Annual Conference, Austin, TX, June 14-17.

Anderson, Kevin, Sandra S. Courter, Mitchell J. Nathan, Amy C. Prevost, Christine G. Nicometo, Traci M. Nathans-Kelly, Thomas D. McGlamery, and Amy K. Atwood. 2011. "Special Session: Moving towards the Intended, Explicit, and Authentic: Addressing Misalignments in Engineering Learning within Secondary and University Education." Proceedings of the American Society for Engineering Education Annual Conference, Vancouver, BC, Canada, June 14-17.

Atman, Cynthia J., Sheri D. Sheppard, Jennifer Turns, Robin S. Adams, Lorraine N. Fleming, Reed Stevens, Ruth A. Streveler, et al. 2010. Enabling Engineering Student Success: The Final Report for the Center for the Advancement of Engineering Education. San Rafael, CA: Morgan \& Claypool Publishers.

Bankel, Johan, Karl-Fredrik Berggren, Karen Blom, Edward F. Crawley, Ingela Wiklund, and Soren Ostlund. 2003. "The CDIO Syllabus: A Comparative Study of Expected Student Proficiency." European Journal of Engineering Education 28 (3): 297-317.

Brunhaver, Samantha, Russell F. Korte, Micah Lande, and Sheri D. Sheppard. 2010. "Supports and Barriers that Recent Engineering Graduates Experience in the Workplace." Proceedings of the American Society for Engineering Education Annual Conference, Louisville, KY, June 20-23.

Bucciarelli, Louis L., and Sarah Kuhn. 1997. "Engineering Education and Engineering Practice: Improving the Fit.” In Technical Work and the Technical Workforce, edited by Stephen R. Barley and Julian E. Orr. Ithaca, NY: Cornell University Press.

Capobianco, Brenda M., Heidi A. Diefes-Dux, Irene Mena, and Jessica Weller. 2011. "What Is an Engineer? Implications of Elementary School Student Conceptions for Engineering Education." Journal of Engineering Education 100 (2): 304-28.

Cappelli, Peter. 2007. Talent on Demand. Cambridge, MA: Harvard Business School Press.

Center for Education. 2008. Research on Future Skill Demands: A Workshop Summary. Washington, D.C.: National Academies Press.

Chubin, Daryl E., Gary S. May, and Eleanor L. Babco. 2005. "Diversifying the Engineering Workforce.” Journal of Engineering Education 94 (1): 73-86.

Colbeck, Carol L., Susan E. Campbell, and Stefani A. Bjorklund. 2000. "Grouping in the Dark: What College Students Learn from Group Projects." Journal of Higher Education 71 (1): 60-83.

Colby, Anne, Thomas Ehrlich, William M. Sullivan, and Jonathan R. Dolle. 2011. Rethinking Undergraduate Business Education: Liberal Learning for the Profession. San Francisco, CA: Jossey-Bass.

Collins, Allan, John Seeley Brown, and Ann Holum. 1991. "Cognitive Apprenticeship: Making Thinking Visible.” American Educator 15 (3): 6-11, 38-39. 
Cooke, Molly, David M. Irby, and Bridget O'Brien. 2010. Educating Physicians: A Call for Reform of Medical School and Residency. San Francisco, CA: Jossey-Bass.

Creswell, John W. 1998. Qualitative Inquiry and Research Design: Choosing among Five Traditions. Thousand Oaks, CA: Sage Publications.

Cunningham, Christine M., Cathy Lachapelle, and Anna Lindgren-Streicher. 2005. "Assessing Elementary Students' Conceptions of Engineering and Technology." Proceedings of the American Society for Engineering Education Annual Conference, Portland, OR, June 12-15.

Douglas, Elliot P., Mirka Koro-Ljungberg, David J. Therriault, Christine S. Lee, and Nathan McNeill. 2012. "Discourses and Social Worlds in Engineering Education: Preparing Problem-Solvers for Engineering Practice." Proceedings of the American Society for Engineering Education Annual Conference, San Antonio, TX, June 10-13.

Duderstadt, James. 2008. Engineering for a Changing World: A Roadmap to the Future of Engineering Practice, Research, and Education. Ann Arbor: University of Michigan.

Dunsmore, Katherine, Jennifer Turns, and Jessica M. Yellin. 2011. "Looking Toward the Real World: Student Conceptions of Engineering." Journal of Engineering Education 100 (2): 1-20.

Dym, Clive L., Alice M. Agogino, Ozgur Eris, Daniel D. Frey, and Larry J. Leifer. 2005. "Engineering Design, Thinking, Teaching, and Learning." Journal of Engineering Education 94 (1): 103-20.

Eliot, Matt, and Jennifer Turns. 2011. "Constructing Professional Portfolios: SenseMaking and Professional Identity Development for Engineering Undergraduates." Journal of Engineering Education 100 (4): 630-54.

Eraut, Michael. 2009. "How Professionals Learn through Work." In Learning to be a Professional through a Higher Education (e-book), edited by Norman Jackson. Accessed Mar. 14, 2015. http://learningtobeprofessional.pbworks.com/w/page $/ 15914952 / \mathrm{How}^{0} \% 20$ professionals $\% 20$ learn $\% 20$ through $\% 20$ work.

Froyd, Jeffrey E., and Matthew W. Ohland. 2005. "Integrated Engineering Curricula." Journal of Engineering Education 94 (1): 147-64.

Grohowski-Nicometo, Christine, Traci Nathans-Kelly, and Kevin J. B. Anderson. 2009. "Work in Progress: Educational Implications of Personal History, Undergraduate Experience, and Professional Values of Practicing Engineers.” Proceedings of the Frontiers in Education Conference, San Antonio, TX, Oct. 18-21.

Grose, Thomas K. 2012. "Steeper Ascent: Should a Master's Be the Minimum for Engineers?" ASEE Prism 21 (9). http://www.prism-magazine.org/summer12/feature 01.cfm.

Grossman, Pamela L., Christa Compton, Danielle Igra, Matthew Ronfeldt, Emily Shahan, and Peter Williamson. 2005. "Unpacking Practice: Decompositions and Approximations." Paper presented at the Annual Meeting of the American Educational Research Association, Montreal, Quebec, Canada, Apr. 11-15.

Haag, Susan, Eric Guilbeau, and Whitney Goble. 2006. "Assessing Engineering Internship Self-Efficacy: Industry's Perception of Student Performance." International Journal of Engineering Education 22 (2): 257-63.

Jamieson, Leah H., and Jack R. Lohmann. 2009. "Creating a Culture for Scholarly and Systematic Innovation in Engineering Education." ASEE Phase 1 Report, American Society for Engineering Education, Washington, D.C.

Jarosz, Jeffrey P., and Ilene J. Busch-Vishniac. 2006. "A Topical Analysis of Mechanical Engineering Curricula.” Journal of Engineering Education 95 (3): 241-48.

Johnson, D. W., R. T. Johnson, and K. A. Smith. 1998. Active Learning: Cooperation in the College Classroom. Edina, MN: Interaction Book Company. 
Jones, Elizabeth A. 2002. "Curriculum Reform in the Professions: Preparing Students for a Changing World." ERIC Clearinghouse on Higher Education, Washington, D.C. https://www.ericdigests.org/2003-4/curriculum-reform.html.

Knight, David B. 2012. "In Search of the Engineers of 2020: An Outcome-Based Typology of Engineering Undergraduates." Proceedings of the American Society for Engineering Education Annual Conference, San Antonio, TX, June 10-13.

Korte, Russell F. 2009. "How Newcomers Learn the Social Norms of an Organization." Human Resource Development Quarterly 20 (3): 285-306.

2010. "First Get to Know Them: A Relational View of Organizational Socialization.” Human Resources Development International 1:27-43.

Korte, Russell, Sheri Sheppard, and William Jordan. 2008. "A Qualitative Study of the Early Work Experiences of Recent Graduates in Engineering." Proceedings of the American Society for Engineering Education Annual Conference, Pittsburgh, PA, June 22-25.

Lattuca, Lisa R., Patrick T. Terenzini, David B. Knight, and Hyun K. Ro. 2014. 2020 Vision: Progress in Preparing the Engineer of the Future. Ann Arbor: University of Michigan, Center for the Study of Higher and Postsecondary Education.

Lattuca, Lisa R., Patrick Terenzini, and J. Fredricks Volkwein. 2006. "A Study of the Impact of EC2020, Full Report.” ABET, Washington, D.C.

Lichtenstein, Gary, Heidi G. Loshbaugh, Brittany Claar, Helen L. Chen, Kristyn Jackson, and Sheri D. Sheppard. 2009. "An Engineering Major Does Not (Necessarily) an Engineer Make: Career Decision-Making among Undergraduate Engineering Majors." Journal of Engineering Education 98 (3): 227-34.

Litzinger, Thomas, Lisa R. Lattuca, Roger Hadgraft, and Wendy Newstetter. 2011. "Engineering Education and the Development of Expertise." Journal of Engineering Education 100 (1): 123-50.

Lowell, B. Lindsay, and Hal Salzman. 2007. Into the Eye of the Storm: Assessing the Evidence on Science and Engineering Education, Quality, and Workforce Demand. Washington, D.C.: Urban Institute.

Matusovich, Holly M., Ruth Streveler, Ronald L. Miller, and Barbara A. Olds. 2009. "I'm Graduating This Year! So What IS an Engineer Anyway?" Proceedings of the American Society for Engineering Education Annual Conference, Austin, TX, June 14-17.

McMasters, J. H., and L. A. Matsch. 1996. "Desired Attributes of an Engineering Graduate." Proceedings of the AIAA Advanced Measurement and Ground Testing Technology Conference, New Orleans, LA, June 17-20.

McNair, Lisa D., Chad Newswander, Daniel Boden, and Maura Borrego. 2011. "Student and Faculty Interdisciplinary Identities in Self-Managed Teams" Journal of Engineering Education 100 (2): 374-96.

Meier, Ronald L., Michael R. Williams, and Michael A. Humphreys. 2000. "Refocusing Our Efforts: Assessing Non-Technical Competency Gaps.” Journal of Engineering Education 89 (3): 377-94.

Miles, Matthew B., and A. Michael Huberman. 1994. Qualitative Data Analysis. Thousand Oaks, CA: Sage Publications.

National Academy of Engineering. 2004. The Engineer of 2020: Visions of Engineering in the New Century. Washington, D.C.: National Academies Press.

- 2005. Educating the Engineer of 2020: Adapting Engineering Education to the New Century. Washington, D.C.: National Academies Press.

- 2008a. Changing the Conversation: Messages for Improving Public Understanding of Engineering. Washington, D.C.: National Academies Press.

—. 2008b. "Grand Challenges in Engineering." Accessed Sept. 1, 2012. http:// www.engineeringchallenges.org. 
National Academy of Engineering and National Research Council. 2009. Engineering in K-12 Education: Understanding the Status and Improving the Prospects. Washington, D.C.: National Academies Press.

National Research Council. 2007. Rising above the Gathering Storm: Energizing and Employing America for a Brighter Economic Future. Washington, D.C.: National Academies Press.

National Science Foundation, National Center for Science and Engineering Statistics, Scientists and Engineers Statistical Data System (SESTAT). 2010. SESTAT Data Tool. Accessed Mar. 14, 2015. http://www.nsf.gov/statistics/sestat.

Oware, Euridice, Brenda Capobianco, and Heidi Diefes-Dux. 2007. "Gifted Students' Perceptions of Engineers? A Study of Students in a Summer Outreach Program." Proceedings of the American Society for Engineering Education Annual Conference, Honolulu, HI, June 24-27.

Parsons, Charles K., Evan Caylor, and Harold S. Simmons. 2005. "Cooperative Education Work Assignments: The Role of Organizational and Individual Factors in Enhancing ABET Competencies and Co-Op Workplace Well-Being." Journal of Engineering Education 94 (3): 309-19.

Passow, Honor J. 2012. "Which ABET Competencies Do Engineering Graduates Find Most Important in Their Work?" Journal of Engineering Education 101 (1): 95-118.

Patton, Michael Q. 2002. Qualitative Research and Evaluation Methods. Thousand Oaks, CA: Sage.

Pawley, Alice L. 2009. "Universalized Narratives: Patterns in How Engineering Faculty Members Define 'Engineering.'” Journal of Engineering Education 98 (4): 309-19.

Perlow, Leslie, and Lotte Bailyn. 1997. "The Senseless Submergence of Difference: Engineers, Their Work, and Their Careers." In Technical Work and the Technical Workforce, edited by Stephen R. Barley and Julian E. Orr. Ithaca, NY: Cornell University Press.

Prince, Michael. 2004. "Does Active Learning Work? A Review of the Research." Journal of Engineering Education 93 (3): 223-31.

Raelin, Joseph A., Margaret B. Bailey, Jerry Hamann, Leslie K. Pendleton, Jonathan Raelin, Rachelle Reisberg, and David Whitman. 2011. "The Effect of Cooperative Education on Change in Self-Efficacy among Undergraduate Students: Introducing Work Self-Efficacy." Journal of Cooperative Education and Internships 45 (2): $17-35$.

Salzman, Hal. 2007. Globalization of $R \& D$ and Innovation: Implications for U.S. STEM Workforce and Policy. Testimony before the U.S. House Subcommittee on Technology and Innovation. Washington, D.C.: Urban Institute.

Salzman, Hal, and Leonard Lynn. 2010. "Engineering and Engineering Skills: What's Really Needed for Global Competitiveness?" Paper presented at the Association for Public Policy Analysis and Management Annual Meeting, Boston, MA, Nov. 4.

Sandelowski, Margarete, Corrine I. Voils, and George Knafl. 2009. "On Quantitizing." Journal of Mixed Methods Research 3 (3): 208-22.

Seering W. 2009. "A Curriculum that Meets Customers' Needs." Paper presented at the NSF workshop "Implementing the Recommendations of 5XME," Orlando, FL, Nov. 12-13.

Sheppard, Sheri D., Cindy Atman, Lorraine Fleming, Ronald Miller, Karl Smith, Reed Stevens, Ruth Streveler, Mia Clark, Tina Loucks-Jaret, and Dennis Lund. 2009. An Overview of the Academic Pathways Study: Research Processes and Procedures. TR-09-03. Seattle, WA: Center for the Advancement for Engineering Education. 
Sheppard, Sheri D., Shannon Gilmartin, Helen L. Chen, Krista Donaldson, Gary Lichtenstein, Özgür Eris, Micah Lande, and George Toye. 2010. Exploring the Engineering Student Experience: Findings from the Academic Pathways of People Learning Engineering Survey (APPLES). TR-10-01. Seattle, WA: Center for the Advancement for Engineering Education.

Sheppard, Sheri D., Kelly Macatangay, Anne Colby, and William M. Sullivan. 2008. Educating Engineers: Designing for the Future of the Field. San Francisco, CA: Jossey-Bass.

Sheppard, Sheri D., Holly M. Matusovich, Cindy Atman, Ruth A. Streveler, and Ronald L. Miller. 2011. "Work in Progress: Engineering Pathways Study: The College-Career Transition." Proceedings of the Frontiers in Education Conference, Rapid City, SD, Oct. 12-15.

Shuman, Larry J., Mary Besterfield-Sacre, and Jack McGourty. 2005. "The ABET 'Professional Skills'-Can They Be Taught? Can They Be Assessed?" Journal of Engineering Education 94 (1): 41-55.

Smith, Karl A., Sheri D. Sheppard, David W. Johnson, and Roger T. Johnson. 2005. "Pedagogies of Engagement: Classroom-Based Practices." Journal of Engineering Education 94 (1): 87-101.

Stake, Robert E. 2006. Multiple Case Study Analysis. New York: Guilford Press.

Steering Committee of the National Engineering Education Research Colloquies. 2006. "The Research Agenda for the New Discipline of Engineering Education." Journal of Engineering Education 95 (4): 259-61.

Sullivan, William M., Anne Colby, Judith Welch Wegner, Lloyd Bond, and Lee S. Shulman. 2007. Educating Lawyers: Preparation for the Profession of Law. San Francisco, CA: Jossey-Bass.

Sullivan, William M., and Matthew S. Rosin. 2008. A New Agenda for Higher Education: Shaping a Life of the Mind for Practice. San Francisco, CA: Jossey-Bass.

Trevelyan, James. 2007. "Technical Coordination in Engineering Practice.” Journal of Engineering Education 96 (3): 191-204.

- 2008. "Longitudinal Study of UWA Engineering Graduates (Class of 2006).” Accessed Sept. 1, 2012. http://school.mech.uwa.edu.au/ jamest/eng -work/long/info-htm.

2009. "Steps toward a Better Model of Engineering Practice." Proceedings of the Research in Engineering Education Symposium, Palm Cove, Queensland, Australia, July 20-23.

- 2010. "Mind the Gaps: Engineering Education and Policy." Proceedings of the Australian Association for Engineering Education Annual Conference, Sydney, Australia, Dec. 5-8.

Trevelyan, James, and Sabbia Tilli. 2008. "Longitudinal Study of Australian Engineering Graduates: Perceptions of Working Time." Proceedings of the American Society for Engineering Education Annual Conference, Pittsburgh, PA, June 22-25.

Vest, Charles M. 2008. "Context and Challenge for Twenty-First Century Engineering Education." Journal of Engineering Education 97 (3): 235-36.

Woods, Donald R. 1994. Problem-Based Learning: How to Gain the Most from PBL. W. L. Griffen: Waterdown, Ontario, Canada.

Yasar, Senay, Dale Baker, Sharon Robinson-Kurpius, Stephen Krause, and Chell Roberts. 2006. "Development of a Survey to Assess K-12 Teachers' Perceptions of Engineers and Familiarity with Teaching Design, Engineering, and Technology." Journal of Engineering Education 95 (3): 205-16.

Yin, Robert K. 2003. Case Study Research: Design and Methods, 3rd ed. Thousand Oaks, CA: Sage Publications. 